The Bangladesh Veterinarian (2019) 36(1 - 2): 33 - 41

\title{
Ultrasound guided diagnosis of anoestrus and its treatment in postpartum crossbred Holstein-Friesian cows
}

\author{
MU Ahmed, MM Rahman, J Bhattacharjee and MMU Bhuiyan* \\ Department of Surgery and Obstetrics, Faculty of Veterinary Science, Bangladesh \\ Agricultural University, Mymensingh-2202, Bangladesh
}

\begin{abstract}
This study was undertaken to determine the feasibility of using ultrasonography for diagnosis of postpartum anoestrus followed by its effective management and treatment in crossbred (Holstein-Friesian X zebu) cows. A total of 57 crossbred lactating cows with unobserved oestrus for $\geq 60$ days postpartum was examined by ultrasonography at Central Cattle Breeding and Dairy Farm (CCBDF), Savar, Dhaka. Cows were divided into silent oestrus and true anoestrus groups by ultrasonography. The pregnancy was diagnosed transrectally using ultrasonography 28 - 35 days after AI. Cows with silent oestrus were treated with Cloprostenol $(500 \mu \mathrm{g})$ followed by AI or with 2 doses of Cloprostenol 10 days apart followed by AI at observed oestrus. The true anoestrus cows were supplied with anthelmintic and vitamin ADE injection with balanced nutrition, treated with Gonadorelin $(500 \mu \mathrm{g})$ followed by AI or with Gonadorelin followed by injecting Cloprostenol at 7 days interval and $\mathrm{AI}$ at observed oestrus. All cows with silent oestrus and true anoestrus were divided into different body condition score (BCS), milk yield, age and parity groups to determine their influence on outcome of treatment. Out of 57 anoestrus cows examined, $56 \%$ were confirmed as silent oestrus and $44 \%$ were confirmed as true anoestrus. In silent oestrus, $71 \%$ cows showed cyclicity and $43 \%$ became pregnant after treatment with Cloprostenol and $78 \%$ cows showed cyclicity and 50\% became pregnant after treatment with 2 doses of Cloprostenol 10 days interval ( $P>0.05)$. In true anoestrus group, $60 \%$ cows showed cyclicity and $40 \%$ became pregnant when balanced diet was supplemented. Around $78 \%$ cows showed cyclicity and $44 \%$ became pregnant after treatment with Gonadorelin and 91\% cows showed cyclicity and 55\% became pregnant when Gonadorelin was followed by Cloprostenol at 7 days interval $(P>0.05)$. Significant $(P<0.05)$ influence of parity was observed in post-treatment cyclicity in true anoestrus cows. (Bangl. vet. 2019. Vol. 36, No. 1 - 2, 33 - 41)
\end{abstract}

\section{Introduction}

Postpartum anoestrus is a major cause of economic loss in dairy and beef industries resulting in increased inter-calving interval (Dziuk and Bellows, 1983). Lengthening the postpartum interval reduces the financial returns by reducing the number of pregnancies, and the cost of treatment. Due to poor nutrition and oestrus detection, prolonged postpartum anoestrus is common and pregnancy rate is low. Around $40 \%$

*Corresponding author:- E-mail: mmubhuiyan@gmail.com; mmubhuiyan@bau.edu.bd

DOI: https://doi.org/10.3329/bvet.v36i1-2.55748 
of postpartum cows were not detected in oestrus when they completed one or more ovarian cycles (Ghosh et al., 1993; Shamsuddin et al., 2001). Poor oestrus detection and prolonged calving interval are major problems for the dairy industry (Shamsuddin, 1995), and missing one oestrus extends calving interval by 21 days causing economic losses of $\$ 11$ (Shamsuddin et al., 2006). In order to achieve an ideal calving interval of one year, a voluntary waiting period of 60 days is required followed by conception within 85 to 90 days after calving (Opsomer et al., 1998).

The calving interval in cows is influenced by the resumption of postpartum ovarian activity (Shrestha et al., 2004). Inactive ovaries are the most important cause of delayed resumption of ovarian cyclicity (Opsomer et al., 1998; de Vries and Veerkamp, 2000). Ovarian cyclicity along with pregnancy and condition of uterus can easily be detected by ultrasonography. Application of ultrasound for management of reproduction in cows is limited in Bangladesh (Rahman, 2010; Islam et al., 2013; Kamal et al., 2014), but it can improve reproductive management (Ginther, 2014). The present study was undertaken to determine the feasibility of using ultrasonography for diagnosis of anoestrus and to determine the effective treatments in crossbred Holstein-Friesian cows.

\section{Materials and Methods}

The investigation was conducted at the Central Cattle Breeding and Dairy Farm (CCBDF), Savar, Dhaka from January to May 2018.

\section{Selection and management of cows}

A total of 57 crossbred (Holstein-Friesian $\mathrm{X}$ zebu) lactating cows with unobserved oestrus for $\geq 60$ days postpartum were selected. Information on farm management, general and reproductive health were collected from register. Age of animals was 4 to 14 years with one to nine parities. Routine deworming against roundworms and liver fluke was done by oral administration of anthelmintics 6 monthly at the rate of 1 bolus per $75 \mathrm{Kg}$ body weight (Levamisole $600 \mathrm{mg}$ + Triclabendazole $900 \mathrm{mg}$; Bolus Renadex ${ }^{\circledR}$, Renata Ltd., Dhaka, Bangladesh). The cows were vaccinated routinely against foot and mouth disease \{Trivalent FMD Vaccine, $6 \mathrm{ml}, \mathrm{s} / \mathrm{c}, 6$ monthly, Livestock Research Institute (LRI), Mohakhali, Dhaka Bangladesh\}, anthrax (Anthrax Vaccine, $1 \mathrm{ml}$, s/c, yearly, LRI, Mohakhali, Dhaka) and haemorrhagic septicaemia (HS vaccine, $2 \mathrm{ml}$, s/c, 6 monthly, LRI, Mohakhali, Dhaka). Cows were housed $24 \mathrm{~h}$ in sheds with natural ventilation. Animals were fed concentrate, green grass and straw twice a day. Cows were milked by hand or milking machine twice daily at an interval of 8-10 h.

\section{Collection of data}

Daily milk yield per cow was taken from the register. Body condition score (BCS) of cows using 1 - 5 scales ( 0.5 fraction between 2 scores) was measured as described by Nicholson and Butterworth (1986). The cows with <2.5 BCS were not selected. 


\section{Examination of reproductive organs by ultrasonography}

The ovaries were examined transrectally using transducer (Easi-Scan Linear, 4.5 to 8.5 $\mathrm{MHz}$ frequency probe, BCF Technology, UK) placed alongside the operator's arm after evacuating faeces. The transducer was lubricated with a coupling medium (Ultrasonic Gel ${ }^{\circledR}$ for Medical use) and covered by a lubricated plastic sleeve. Cows were divided into two groups (silent oestrus and true anoestrus). Cows with corpus luteum (CL) with normal uterus were regarded as silent oestrus. Cows without CL and follicles, smooth relatively small ovaries and normal uterus when examined 10 days apart were considered as having true anoestrus.

\section{Treatment protocol and artificial insemination (AI)}

AI was done at observed oestrus by trained technician using frozen semen. Pregnancy was confirmed by ultrasonography (Easi-Scan Linear) 28 to 35 days after AI. Fourteen cows with silent oestrus were treated with $\mathrm{PGF}_{2} \mathrm{a}$ analogue (Cloprostenol sodium $500 \mu \mathrm{g}$; Ovuprost ${ }^{\circledR}$, Bayer New Zealand Ltd., Auckland, New Zealand) injection (i/m) followed by AI at observed oestrus. Other 18 cows were treated with two injections of PGF2 $\alpha$ analogue at an interval of 10 days followed by AI at observed oestrus. Of the 25 true anoestrous cows, five were treated with anthelmintic (Bolus Renadex ${ }^{\circledR}$, Renata Ltd., Dhaka, Bangladesh) and vitamin ADE injection $(10 \mathrm{ml} \mathrm{i} / \mathrm{m}$, weekly for 4 weeks, Injection Renasol ${ }^{\circledR} \mathrm{AD}_{3} \mathrm{E}$, Vitamin A $500000 \mathrm{IU}, \mathrm{D}_{3} 75000 \mathrm{IU}$ and $\mathrm{E} 50 \mathrm{mg}$ per ml, Renata Ltd., Dhaka, Bangladesh) and fed concentrate supplement [Maize (50\%), Wheat bran $(30 \%)$, Oil cake $(10 \%)$, Rice polish $(8 \%)$ and Vitamin-Mineral premixes $(2 \%)$ ]; nine cows were treated with GnRH analogue i/m (Gonadorelin $500 \mu \mathrm{g}$, Ovurelin ${ }^{\circledR}$, Bayer New Zealand Ltd.) followed by AI at observed oestrus; and 11 cows were treated with GnRH analogue followed by PGF2a analogue i/m at 7 days interval and AI was done at observed oestrus.

Moreover, all cows with silent oestrus and true anoestrus were grouped into 2.5, 3.0 and 3.5 BCS, 6-8, 9-11 and 12-19 litres milk yield daily, 4-6, 7-9, 10-14 years of age, and 1-3, 4-6 and 7-9 parities for determining their influence on treatment response.

\section{Statistical analysis}

The data were entered in Microsoft Excel 2007 and descriptive statistics were performed. The data were analysed by paired $t$ test using MINITAB version 13 statistical programme. The difference between values was considered significant when the P value was less than 0.05 .

\section{Results and Discussion}

Out of 57 anoestrus cows examined by ultrasonography at 60 or more days postpartum, $32(56 \%)$ were confirmed as silent or unobserved oestrus and $25(44 \%)$ as true anoestrus. More than half of the anoestrus cows missed one or more cycles. Pregnancy was confirmed using ultrasonography at 28 to 35 days, earlier than rectal examination at 60 to 90 days. Earlier identification of non-pregnancy allows earlier 
re-insemination. This indicates the feasibility of using ultrasonography in cows under field conditions in Bangladesh. Application of ultrasound as a tool to improve reproductive management of cattle is documented (Ginther, 2014). Application of ultrasound for management of reproductive problems and pregnancy diagnosis in cows has been reported in Bangladesh (Rahman, 2010; Islam et al., 2013; Kamal et al., 2014).

Treatment regime of anoestrus cows is presented in Table 1. Cows with silent oestrus showed cyclicity $(71 \%)$ and became pregnant $(43 \%)$ when treated with $\mathrm{PGF}_{2} \mathrm{a}$ followed by AI at observed oestrus. Cows showed cyclicity (78\%) and became pregnant $(50 \%)$ when treated with two injections of $\mathrm{PGF}_{2} \mathrm{a}$ at an interval of 10 days followed by AI. True anoestrus cows showed cyclicity (60\%) and became pregnant (40\%) when supplemented with concentrates. When GnRH was administered, 78\% cows showed cyclicity and $44 \%$ became pregnant after AI at observed oestrus. Around $91 \%$ cows showed cyclicity and 55\% became pregnant after GnRH administration followed by $\mathrm{PGF}_{2} \mathrm{\alpha}$ at 7 days interval and $\mathrm{AI}$ at observed oestrus. Cows not detected in oestrus, but with CL were treated with $\mathrm{PGF}_{2}$ a. Smith et al. (1998) reported that treatment of anoestrus cows with detectable CL with $\mathrm{PGF}_{2} \mathrm{a}$ resulted in oestrus in 55\% of animals within six days of treatment. When the CL was detected following rectal palpation, oestrous response rate within six days of treatment was 52\% (Whittier et al., 1989). Further, treatment of true anoestrus can be done by Ovsynch protocol, GnRH followed by $\mathrm{PGF}_{2} \mathrm{a}$ at 7 days interval and $\mathrm{AI}$ at observed oestrus with another injection of GnRH (Stevenson et al., 1996; Peters et al., 1999). Similar cyclicity was reported by Kamal et al. (2012) in true anoestrus cows when Ovsynch protocol were used, but lower pregnancy rate was reported.

Table 1: Effects of treatment of anoestrus crossbred cows on induction of cyclicity and pregnancy

\begin{tabular}{|c|c|c|c|c|}
\hline \multirow{2}{*}{$\begin{array}{c}\text { Type of } \\
\text { anoestrus }\end{array}$} & \multirow[t]{2}{*}{ Treatments } & \multirow{2}{*}{$\begin{array}{c}\text { Number of } \\
\text { cows } \\
\text { treated }\end{array}$} & \multicolumn{2}{|c|}{ Response to treatment } \\
\hline & & & $\begin{array}{l}\text { No. }(\%) \text { of cows } \\
\text { showed cyclicity }\end{array}$ & $\begin{array}{l}\text { No. (\%) of cows } \\
\text { became pregnant }\end{array}$ \\
\hline \multirow{3}{*}{$\begin{array}{l}\text { Silent } \\
\text { oestrus }\end{array}$} & $\mathrm{PGF}_{2} \mathrm{a}+\mathrm{AI}$ at observed oestrus & 14 & $10(71)$ & $6(43)$ \\
\hline & $\begin{array}{l}\mathrm{PGF}_{2} \mathrm{\alpha}+\text { after } 10 \text { days } \mathrm{PGF}_{2} \mathrm{\alpha}+\mathrm{AI} \text { at } \\
\text { observed oestrus }\end{array}$ & 18 & $14(78)$ & $9(50)$ \\
\hline & Total & 32 & $24(75)$ & $15(47)$ \\
\hline \multirow{4}{*}{$\begin{array}{l}\text { True } \\
\text { anoestrus }\end{array}$} & Deworming +Nutrition+ADE & 5 & $3(60)$ & $2(40)$ \\
\hline & $\mathrm{GnRH}+\mathrm{AI}$ at observed oestrus & 9 & $7(78)$ & $4(44)$ \\
\hline & $\begin{array}{l}\text { GnRH }+ \text { after } 7 \text { days } \mathrm{PGF}_{2} \mathrm{a}+\mathrm{AI} \text { at } \\
\text { observed oestrus }\end{array}$ & 11 & $10(91)$ & $6(55)$ \\
\hline & Total & 25 & $20(80)$ & $12(48)$ \\
\hline
\end{tabular}

Percentage values within same column did not vary significantly between each other $(\mathrm{P}>0.05)$. 
Influence of BCS of treated anoestrus crossbred cows on induction of cyclicity and pregnancy is presented in Table 2: 50 to 100\% cows showed cyclicity and 25 to $67 \%$ became pregnant $(\mathrm{P}>0.05)$. The nutrition has tremendous impact on reproduction (Bindari et al., 2013). Malnutrition results in the loss of body weight and body condition, interfering with ovarian cyclicity by decreasing gonadotrophin secretion followed by prolonged post-partum anoestrus (Boland et al., 2001). Chronic nutritional deficiencies may lead to subfertility by interrupting hypothalamopituitary-ovarian axis function in dairy cows (Dobson and Alam, 1987). Affected cows not only delay ovarian cyclicity, but have poor oestrus signs resulting in error in oestrus detection and breeding time, and reduced pregnancy rate (Gumen et al., 2003). As cows with less than 2.5 BCS were excluded, all treated cows had good cyclicity and pregnancy rates.

Table 2: Influence of BCS of treated anoestrus crossbred cows on induction of cyclicity and pregnancy

\begin{tabular}{l|c|c|c|c}
\hline \multicolumn{1}{c}{$\begin{array}{c}\text { Type of } \\
\text { anoestrus }\end{array}$} & BCS & \multirow{2}{*}{$\begin{array}{c}\text { Number of cows } \\
\text { treated }\end{array}$} & \multicolumn{2}{c}{ Response to treatment } \\
\cline { 4 - 5 } & & & $\begin{array}{c}\text { No. (\%) of cows } \\
\text { showed cyclicity }\end{array}$ & $\begin{array}{c}\text { No. (\%) of cows } \\
\text { became pregnant }\end{array}$ \\
\hline Silent & 2.5 & 9 & $7(78)$ & $6(67)$ \\
oestrus & 3.0 & 20 & $14(70)$ & $7(35)$ \\
& 3.5 & 3 & $3(100)$ & $2(67)$ \\
\hline True & 2.5 & 8 & $4(50)$ & $2(25)$ \\
anoestrus & 3.0 & 13 & $11(85)$ & $8(62)$ \\
& 3.5 & 4 & $4(100)$ & $2(50)$ \\
\hline
\end{tabular}

Percentage values within same column did not vary significantly between each other $(\mathrm{P}>0.05)$.

Influence of milk yield of treated anoestrus crossbred cows on induction of cyclicity and pregnancy is presented in Table 3: 56 to $100 \%$ cows showed cyclicity and 29 to $71 \%$ became pregnant $(\mathrm{P}>0.05)$. Higher milk yield may delay onset of oestrous cycles if associated with exacerbated negative energy balance. However, milk yield is closely associated with dry matter intake (Liefers et al., 2003), and energy intakes accounted for most of the variation in energy balance in postpartum cows (Villa-Godoy et al., 1988). Milk yield had no influence on the treatment response in crossbred anoestrus cows. This may be because cows selected were not suffering from negative energy balance during lactation (2.5 to $3.5 \mathrm{BCS})$.

Influence of age of treated anoestrus crossbred cows on induction of cyclicity and pregnancy is presented in Table 4: 55 to 100\% cows showed cyclicity and 36 to $67 \%$ became pregnant $(\mathrm{P}>0.05)$. Influence of age on onset of postpartum cyclicity in bovine has been reported by Williams and Griffith (1995). It is likely that age of animals has little influence on reproductive performance if the animal does not suffer from 
malnutrition or negative energy balance, or stress due to suckling and environment. Nutrition supplementation and restricted suckling were followed.

Table 3: Influence of milk yield of treated anoestrus crossbred cows on induction of cyclicity and pregnancy

\begin{tabular}{l|c|c|c|c}
\hline \multicolumn{1}{c}{$\begin{array}{c}\text { Type of } \\
\text { anoestrus }\end{array}$} & $\begin{array}{c}\text { Milk yield } \\
(\mathrm{L})\end{array}$ & \multirow{2}{*}{$\begin{array}{c}\text { Number of } \\
\text { cows treated }\end{array}$} & & \multicolumn{2}{|c}{ Response to treatment } \\
\cline { 4 - 5 } & & & $\begin{array}{c}\text { No. (\%) of cows } \\
\text { showed cyclicity }\end{array}$ & $\begin{array}{c}\text { No. (\%) of cows } \\
\text { became pregnant }\end{array}$ \\
\hline Silent & $6-8$ & 8 & $6(75)$ & $5(63)$ \\
oestrus & $9-11$ & 17 & $12(71)$ & $5(29)$ \\
& $12-14$ & 7 & $6(86)$ & $5(71)$ \\
\hline True & $6-8$ & 9 & $5(56)$ & $4(44)$ \\
anoestrus & $9-11$ & 13 & $11(85)$ & $7(54)$ \\
& $12-14$ & 3 & $3(100)$ & $1(33)$ \\
\hline
\end{tabular}

Percentage values within same column did not vary significantly between each other $(P>0.05)$.

Table 4: Influence of age of treated anoestrus crossbred cows on induction of cyclicity and pregnancy

\begin{tabular}{l|c|c|c|c}
\hline \multirow{1}{*}{$\begin{array}{c}\text { Type of } \\
\text { anoestrus }\end{array}$} & Age (Years) & $\begin{array}{c}\text { Number of } \\
\text { cows treated }\end{array}$ & & \multicolumn{2}{c}{ Response to treatment } \\
\cline { 4 - 5 } & & & $\begin{array}{c}\text { No. (\%) of cows } \\
\text { showed cyclicity }\end{array}$ & $\begin{array}{c}\text { No. (\%) of cows } \\
\text { became pregnant }\end{array}$ \\
\hline Silent & $4-6$ & 8 & $6(75)$ & $4(50)$ \\
oestrus & $7-9$ & 16 & $12(75)$ & $7(44)$ \\
& $10-14$ & 8 & $6(75)$ & $4(50)$ \\
\hline True & $4-6$ & 3 & $3(100)$ & $2(67)$ \\
anoestrus & $7-9$ & 11 & $10(91)$ & $6(55)$ \\
& $10-14$ & 11 & $6(55)$ & $4(36)$ \\
\hline
\end{tabular}

Percentage values within same column did not vary significantly between each other $(\mathrm{P}>0.05)$.

Influence of parity of treated anoestrus crossbred cows on induction of cyclicity and pregnancy is presented in Table 5: 60 to $100 \%$ cows showed cyclicity and 20 to $50 \%$ became pregnant. The proportion of true anoestrus cows cycling varied significantly $(\mathrm{P}<0.05)$ between $1-3$ and $4-9$ parity groups. The result in parity $1-3$ is not consistent with earlier reports, because primiparous cows had greater concentrations of blood non-esterified fatty acids (NEFA) than multiparous cows one week before parturition (Meikle et al., 2004) and early postpartum cows (Meikle et al., 2004; Wathes et al., 2007). Elevated NEFA and ketone bodies before parturition are related to reduced periparturient immunological function and uterine disease (Hammon et al., 2006), which are known to influence postpartum ovulation (Sheldon et al. 2002). 
Primiparous cows typically have more early postpartum uterine problems (Goshen and Shpigel, 2006), which can delay resumption of ovulation. Cows diagnosed with uterine infection have dominant ovarian follicles that grew at a slower rate than those without uterine problems (Sheldon et al., 2002). It is possible that primiparous cows might be more sensitive to metabolic and endocrine signals during the periparturient period such as those influenced by the nutrient balance and by alterations in uterine health, thereby delaying the resumption of postpartum ovulation. It is noteworthy to mention that most of the cows were with parity 2 - 3 and only two true anoestrus cows with $1^{\text {st }}$ parity were included in 1 - 3 parity group which might influence the present results.

Table 5: Influence of parity of treated anoestrus crossbred cows on induction of cyclicity and pregnancy

\begin{tabular}{|c|c|c|c|c|}
\hline \multirow{2}{*}{$\begin{array}{l}\text { Type of } \\
\text { anoestrus }\end{array}$} & \multirow[t]{2}{*}{ Parity } & \multirow{2}{*}{$\begin{array}{l}\text { Number of } \\
\text { cows treated }\end{array}$} & \multicolumn{2}{|c|}{ Response to treatment } \\
\hline & & & $\begin{array}{l}\text { No. (\%) of cows } \\
\text { showed cyclicity }\end{array}$ & $\begin{array}{l}\text { No. }(\%) \text { of cows } \\
\text { became pregnant }\end{array}$ \\
\hline \multirow{3}{*}{$\begin{array}{l}\text { Silent } \\
\text { oestrus }\end{array}$} & $1-3$ & 18 & $14(78)$ & $8(44)$ \\
\hline & $4-6$ & 12 & $8(67)$ & $6(50)$ \\
\hline & $7-9$ & 2 & $2(100)$ & $1(50)$ \\
\hline \multirow{3}{*}{$\begin{array}{l}\text { True } \\
\text { anoestrus }\end{array}$} & $1-3$ & 10 & $10(100)^{a}$ & $6(50)$ \\
\hline & $4-6$ & 10 & $6(60)^{b}$ & $5(50)$ \\
\hline & $7-9$ & 5 & $3(60)^{b}$ & $1(20)$ \\
\hline
\end{tabular}

a,b Percentage values with superscripts within same column varied significantly between each other $(\mathrm{P}<0.05)$.

\section{Conclusions}

Use of ultrasonography is feasible to diagnose anoestrus and pregnancy in cows. The treatment protocol initiated cyclicity in $>60 \%$ cows with $>40 \%$ pregnancy in anoestrus crossbred Holstein-Friesian cows. Significant influence of parity was observed in posttreatment cyclicity in true anoestrus cows. This study will help the practising veterinarians to deal with the anoestrous cows efficiently. Further investigation with a greater number of animals is needed to draw more definite conclusions.

\section{Acknowledgements}

The authors acknowledge Bangladesh Agricultural University Research System (BAURES) for funding through the research project \# 2017/240/BAU. Department of Livestock Services (DLS), People's Republic of Bangladesh is also acknowledged for allowing us to conduct the study at the Central Cattle Breeding and Dairy Farm, Savar, Dhaka. 


\section{References}

Bindari YR, Shrestha S, Shrestha N, Gaire TN 2013: Effects of nutrition on reproduction- a review. Advances in Applied Science Research 4 421-429.

Boland MP, Lonergan P, Callaghan O 2001: Effect of nutrition on endocrine parameters, ovarian physiology, and oocyte and embryo development. Theriogenology 55 1323-1340.

deVries MJ, Veerkamp RF 2000: Energy balance of dairy cattle in relation to milk production variables and fertility. Journal of Dairy Science 83 62-69.

Dobson H, Alam MGS 1987: Preliminary investigation into the endocrine feedback system of subfertile cattle: location of a common lesion (rate limiting step). Journal of Endocrinology 113 167-171.

Ghosh A, Alam MGS, Akbar MA 1993: Effects of urea-molasses mineral block supplementation on postpartum ovarian activity in zebu cows. Animal Reproduction Science 31 61-67.

Ginther OJ 2014: How ultrasound technologies have expanded and revolutionized research in reproduction in large animals. Theriogenology 81 112-125.

Goshen T, Shpigel NY 2006. Evaluation of intrauterine antibiotic treatment of clinical metritis and retained fetal membranes in dairy cows. Theriogenology 66 2210-2218.

Gumen A, Guenther JN, Wiltbank MC 2003: Follicular size and response to Ovsynch versus detection of oestrus in anovular and ovular lactating dairy cows. Journal of Dairy Science 86 3184-3194.

Hammon DS, Evjen IM, Dhiman TR, Goff JP, Walters JL 2006: Neutrophil function and energy status in Holstein cows with uterine health disorders. Veterinary Immunology and Immunopathology 113 21-29.

Islam MR, Juyena NS, Bhuiyan MMU, Rahman MM, Ferdousy RN 2013: Treatment outcomes in postpartum anoestrus cows guided by transrectal ultrasonography. Progressive Agriculturist 24 93-100.

Kamal MM, Bhuiyan MMU, Parveen N, Momont HW, Shamsuddin M 2014: Risk factors for the postpartum anestrus in crossbred cows in Bangladesh. Turkish Journal of Veterinary and Animal Sciences 38 151-156.

Kamal MM, Rahman MM, Momont HW, Shamsuddin M 2012: Underlying disorders of postpartum anoestrus and effectiveness of their treatments in crossbred dairy cows. Asian Journal of Animal Sciences 6 132-139.

Liefers SC, Veerkamp RF, Te Pas MF, Delavaud C, Chilliard Y, van der Lende T 2003: Leptin concentrations in relation to energy balance, milk yield, intake, live weight and oestrus in dairy cows. Journal of Dairy Science 86 799-807.

Meikle A, Kulcsar M, Chilliard Y, Febel H, Delavaud C, Cavestany D, Chilibroste P 2004: Effects of parity and body condition at parturition on endocrine and reproductive parameters of the cow. Reproduction 127 727- 737.

Nicholson MJ, Butterworth MH 1986: A guide to condition scoring of zebu cattle. International Livestock Centre for Africa, Addis Ababa, Ethiopia, pp. 212-235. 
Opsomer G, Coryn M, Deluyker H, de Kruif A 1998: An analysis of ovarian dysfunction in high yielding dairy cows after calving based on progesterone profiles. Reproduction in Domestic Animals 33 193-204.

Peters AR, Ward SJ, Warren MJ, Gordon PJ, Mann GE, Webb R 1999: Ovarian and hormonal responses of cows to treatment with an analogue of gonadotropin releasing hormone and prostaglandin $\mathrm{F}_{2} \mathrm{a}$. The Veterinary Record 144 343-346.

Rahman MM 2010: Management and effective treatment of postpartum anoestrus cows guided by ultrasonography. MS in Theriogenology Thesis. Department of Surgery and Obstetrics, Faculty of Veterinary Science, Bangladesh Agricultural University, Mymensingh, Bangladesh.

Shamsuddin M 1995: Fertility trend and status of oestrus detection in the bovine under farm conditions in Bangladesh. Bangladesh Veterinary Journal 29 9-16.

Shamsuddin M, Bhuiyan MMU, Chanda PK, Alam MGS, Galloway D 2006: Radioimmunoassay of milk progesterone as a tool for fertility control in smallholder dairy farms. Tropical Animal Health and Production 38 85-92.

Shamsuddin M, Bhuiyan MMU, Sikder TK, Sugulle AH, Chanda PK, Alam MGS, Galloway D 2001. Constraints limiting the efficiency of artificial insemination of cattle in Bangladesh. In Radioimmunoassay and Related Techniques to Improve Artificial Insemination Programmes for Cattle Reared under Tropical and Sub-tropical Conditions. IAEA-TECDOC-1220 pp. 9-27.

Sheldon IM, Noakes DE, Rycroft AN, Pfeiffer DU, Dobson H 2002: Influence of uterine bacterial contamination after parturition on ovarian dominant follicle selection and follicle growth and function in cattle. Reproduction 123 837-845.

Shrestha HK, Nakao T, Higaki T, Suzuki T, Akita M 2004: Resumption of postpartum ovarian cyclicity in high-producing Holstein cows. Theriogenology 61 637-649.

Smith ST, Ward WR, Dobson H 1998. Use of ultrasonography to help to predict observed oestrus in dairy cows after the administration of prostaglandin $\mathrm{F}_{2} \mathrm{a}$. The Veterinary Record 142 271-274.

Stevenson JS, Kobayashi Y, Shipka MP, Rauchholz KC 1996: Altering conception of dairy cattle by gonadotropin-releasing hormone preceding luteolysis induced by prostaglandin F2a. Journal of Dairy Science 79 402- 410.

Villa-Godoy A, Hughes TL, Emery RS, Chapin LT, Fogwell RL 1988. Association between energy balance and luteal function in lactating dairy cows. Journal of Dairy Science $\mathbf{7 1}$ 1063-1072.

Wathes DC, Cheng Z, Bourne N, Taylor VJ, Coffey MP, Brotherstone S 2007: Differences between primiparous and multiparous dairy cows in the inter-relationships between metabolic traits, milk yield and body condition score in the periparturient period. Domestic Animal Endocrinology 33 203-225.

Whittier WD, Gwazdauskas FC, McGilliard ML 1989: Prostaglandin $F_{2} \alpha$ usage in a dairy reproduction program for treatment of unobserved oestrus, pyometra and ovarian luteal cysts. Theriogenology 32 693-704.

Williams GL, Griffith MK 1995: Sensory and behavioural control of gonadotrophin secretion during suckling-mediated anovulation in cows. Journal of Reproduction and Fertility (Suppl.) 49 463-475. 